Narcissism in Toronto: Jones, Freud, and Minor Differences

Peter Buse

Faculty of Arts and Social Sciences, Kingston University, London, UK

Penrhyn Road, Kingston, KT1 2EE

p.buse@kingston.ac.uk

Peter Buse is Associate Dean for Research (Arts and Social Sciences) at Kingston University, London. He is the author, most recently of The

Camera Does the Rest: How Polaroid Changed Photography (Chicago: University of Chicago Press, 2016).

Orcid I.D.: 0000-0001-8350-4228

8300 words, including endnotes 


\title{
Narcissism in Toronto: Jones, Freud, and Minor Differences
}

\begin{abstract}
This article conducts a genealogy of Freud's never fully-developed concept of the narcissism of minor differences, which first appears in his writings in 1917, and then three more times with slight variations. It starts with an earlier articulation of the concept in 1908 in a letter from Ernest Jones in Canada to Freud. The article outlines the background to Jones' presence in Canada and his assessment of Canadians, and goes on to argue that in its subtle differences from Freud, Jones' version of the concept provides a clarification of what is essential in Freud's version. Among the questions it helps us answer is whether minor differences beget narcissism or narcissism cathects minor differences. In other words, tracing the path by which the idea develops tells us something interesting about its eventual shape. The article concludes that Freud does not so much borrow from Jones, as provide an analysis of Jones' letter through his modifications of it. The article finishes by arguing that the concept provides a different route into the philosophical and psychoanalytic question of the love of the neighbor, an issue central to the ethics of Jacques Lacan, and subsequently to Žižek and Santner.
\end{abstract}

Keywords: Narcissism of minor differences; Ernest Jones, Freud, the neighbor, Canada

A minimal chronicle of the early history of Anglophone psychoanalysis would include at least the following: Sigmund Freud and Carl Jung's English and American patients in Vienna and Zurich; Abraham Brill's first translations of Freud into English in New York; and Freud, Jung and Sándor Ferenczi’s voyage to the New World in 1909, bringing with them 'the plague', as Freud told Jung on the boat before he delivered the Clark Lectures in Worcester, Massachusetts. ${ }^{1}$ To this list could also be added a lesser known foray by the Welsh analyst, Ernest Jones, who spent four years between 1908 and 1913 in Toronto, Canada, in what he considered exile from Europe and from the centres of psychoanalysis. Jones built alliances, disseminated psychoanalytic ideas, and advanced the cause in North America in those four years, 
but his direct impact on his host country is more difficult to gauge. What is certain is that he mostly disliked Canada and was happy to leave it.

The assessment that Jones made of the country and its inhabitants in his first months there in a letter to Freud was far from flattering, but of considerable interest for the history of psychoanalysis: 'Well, Canada is larger than Europe [...] and has the population of London' Jones informed Freud in December 1908, going on, Toronto is a prettily built town, though the architecture is extremely mixed. Music is rare here, and there is not a picture gallery in the country. The people are 19 parts American, and one part Colonial, therefore are very insulted if called Americans. I have always noticed that the more difficult it is to distinguish people (e.g. Norwegians and Swedes, Flemish and Dutch, Spanish and Portuguese), the more insulted they feel at being confused with each other. They are a despicable race, exceedingly bourgeois, quite uncultured, very rude, very stupid and very narrow and pious. They are naïve, childish and hold the simplest views of life. They care for nothing except money-making and sport, they chew gum instead of smoking or drinking, and their public meetings are monuments of sentimental platitudes. They are horror-struck with me because I don't know the date of the King's birthday, for they take their loyalty like everything else in dead seriousness and have no sense of humour. ${ }^{2}$

The first part of Jones’ complaint about Canadians - his dismissal of their sensitivity about being mistaken for Americans - bears a striking resemblance to Freud's concept of 'the narcissism of minor differences'. Compare Jones’ words, for instance, with these ones published by Freud more than twenty years later in Civilization and its Discontents: 
It is always possible to bind together a considerable number of people in love, so long as there are other people left over to receive the manifestations of their aggressiveness. I once discussed the phenomenon that is precisely communities with adjoining territories, and related to each other in other ways as well (gerade benachbarte und einander auch sonst nahestehende Gemeinschaften), who are engaged in constant feuds and in ridiculing each other - like the Spaniards and Portuguese, for instance, the North Germans and South Germans, the English and Scotch, and so on. I gave this phenomenon the name of 'the narcissism of minor differences’ (der Narzißmus der kleinen Differenzen), a name which does not do much to explain it. We can now see that it is a convenient and relatively harmless satisfaction of the inclination to aggression, by means of which cohesion between the members of the community is made easier. In this respect the Jewish people, scattered everywhere, have rendered most useful services to the civilizations of the countries that have been their hosts. $^{3}$

The narcissism of minor differences is scattered through Freud's writings, but is never the subject of a separate essay or inquiry. The concept has nevertheless found considerable purchase beyond psychoanalysis. It attracted particular attention in the 1990s in the wake of civil wars and atrocities in the former Yugoslavia and Rwanda for its apparent explanatory power. Michael Ignatieff, for instance, draws on it to try to understand the formation of mutually hostile 'ethnic' groupings in the wake of failed states, where no such groupings existed previously. ${ }^{4}$ In another register, it is seen retrospectively as a framework for a theory of social stratification developed in the work of sociologists such as Pierre Bourdieu, who argues that 'Social identity lies 
in difference, and difference is asserted against what is closest, which represents the

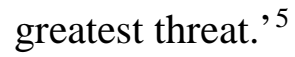

The concept has also attracted criticism. Brett St Louis notes its usefulness, but worries about Freud's apparent naturalization of the conflicts that arise from minor differences: ‘Freud's inability to concretely understand why groups should be so acutely receptive to such “details of differentiation” becomes problematic in the temptation to explain it as an "elementary character" which is magnified by summation of its benign form that disregards its pernicious effects'. ${ }^{6}$ Others claim that Freud underestimated the ways in which small differences might become the justification for extreme violence. ${ }^{7}$ However, given the limited material on which to make judgments, and the subtle changes Freud's terminology undergoes over twenty years, any criticism can only be provisional. As St Louis puts it, 'by [Freud's] own standards, the "narcissism of minor differences" is extremely underdeveloped and must be considered more a notion than a concept' ${ }^{8}$ And as Freud said himself in Civilization and its Discontents, the 'name [...] does not do much to explain' the phenomenon. In this light, Jones’s letter of 1908 takes on greater significance, adding a fifth primary text on the narcissism of minor differences, and allowing not only for a longer genealogy of Freud's idea, but in its subtle difference from Freud, a clarification of what is essential in Freud's version. Not the least of the questions it helps us answer is whether minor differences beget narcissism or narcissism cathects minor differences. In other words, tracing the path by which the idea develops will tell us something interesting about its eventual shape. It will also provide a different route into the philosophical and psychoanalytic question of the neighbor, for which another part of Civilization and its Discontents is the usual starting point. 


\section{Jones in Canada}

Ernest Jones went unwillingly to Canada, leaving behind scandal in England, forced into resigning his post at a London hospital after the parents of a ten-year old girl complained when he sought out a sexual etiology for an hysterical paralysis in her arm. These were the first fruits of Jones's initial encounter with Freud, in April 1908 at the inaugural International Psychoanalytical Congress in Salzburg. Jones soon became a trusted member of Freud's inner circle, the only Gentile in the seven-strong secret 'Committee' dedicated to defending psychoanalysis from its detractors and apostates. He was also a founder and future President of the International Psychoanalytic Association, first President of the British Psychoanalytic Society (1919) and first editor of the International Journal of Psychoanalysis (1920). Known for his political zeal and organizational acumen, he identified intensely with psychoanalysis as an institution, and was more dogmatic about its precepts than Freud ever was. ${ }^{9}$ So devoted was he to the Cause that he became known as 'Freud's Rottweiler'. But before that Jones endured four years of exile across the Atlantic, where Freud, in their long correspondence, encouraged him to stay, in order to stabilise and extend the psychoanalytic beachhead in America. ${ }^{10}$

Like many who are desperate to return from whence they came, Jones’s work rate in Toronto was prolific. Shortly after his arrival in September 1908 to take up a post at the University of Toronto, the UCL-trained neurologist established a private clinic specializing in 'nervous diseases' at 407 Brunswick Avenue. In addition to his private analytic practice, he was soon promoted to Associate Professor at the University, and moonlighted as assistant psychiatrist at the General Hospital. ${ }^{11}$ When the publication of Freud's Clark Lectures brought prestige to psychoanalysis, Jones attracted more analysands, both Canadians and Americans who crossed the border to 
see him, including among them the daughter of William Meredith, the University's Chancellor, an analysis that by all accounts had a successful outcome. The hazards of a new science that gave such importance to sex were as real in Toronto as they were in London, and he required police protection after a former patient threatened to shoot him, accusing him of having sexual relations with her. In the end the patient was paid off with a sum of $\$ 500$, amounting to a year's salary for Jones. Throughout the affair he had the full support of Robert Alexander Falconer, Bible scholar and President of the University of Toronto.

All this gave Jones ample case material to write up, and it was the most productive period of his life: he published a total of 70 articles in the technical journals in his years in Canada. Among these were his essay 'On the Nightmare' and the first version of a landmark piece of Shakespeare criticism, his paper on Hamlet, published in January 1910 in the American Journal of Psychology as 'The Oedipus Complex as an Explanation of Hamlet's Mystery.' He served as assistant editor of the Journal of Abnormal Psychology from 1908 and reviewed and abstracted for six further journals in Europe. In Toronto he also acted as co-editor of the Bulletin of the Ontario Hospitals for the Insane, alienating his fellow editors and contributors by taking up three quarters of the space with his own work. He was asked to leave the journal after publishing an article about a patient who mimicked oral sex whilst comparing it to the sacrament. ${ }^{12}$ In 1913 the University turned down his request to split his year between London and Toronto, so he resigned his post and returned full time to England, where he established that same year the London Psychoanalytical Society. 


\section{Canada, America, Psychoanalysis}

In his autobiography, Free Associations, Jones credits his productivity to the weather, which was either too cold or too hot, with September the 'one tolerable month' in Toronto. ${ }^{13}$ Nevertheless, he says that

Life in Toronto was in many ways very pleasant. Curiously enough, one partook of cultural activities more than in London. There, where so many were available, one had to make an effort to find the necessary time. In Toronto there was only one serious centre, the Massey Hall, and everything that came there did so only for a week. So it became always a weekly habit to attend, and it was very rewarding, since the most celebrated artists of the musical and theatrical world always included Toronto in their American tours. Any gap would be filled by the Montreal Opera Company, which was very good indeed. Then there were regular visits from the magnificent American orchestras, with their famous conductors, all on a level which London has never reached. ${ }^{14}$

Records indicate that Harry Lauder, Ellen Terry and Isadora Duncan, among others, appeared at Massey Hall while Jones was in Toronto. ${ }^{15}$ On the day of Jones’ letter to Freud on the Canadians, Gilbert and Sullivan’s Iolanthe was beginning a three-night run. Also appearing regularly at Massey Hall during Jones’ Canadian sojourn were the Sons of Scotland, the Loyal Orange Lodge, and the Ancient Order of Hibernians, each one catering for a different ethnic particularity. There is no evidence of an expatriate Welsh organization booking the Hall.

Jones’ praise for Toronto cultural life may be an example of what he calls his 'newly-won tactfulness' in a country where 'sensitiveness to criticism' was ‘a national characteristic'. ${ }^{16}$ Biographers give a less complimentary account of his views of Canada. T.G. Davies notes that, 
While living in Canada, [Jones] was frequently reminded of the pressures of the Victorian influences to which he was subjected as a child, and his overtolerant attitude in sexual matters did not endear him to the people of a city that boasted the name Toronto the Good. He [...] longed so much for life in Europe that he joined the city’s German Club. ${ }^{17}$

The rigidity of Upper Canada morality might have provided rich clinical material, but no city with an elevated notion of its own goodness could be expected to tolerate, never mind openly embrace, psychoanalytic thinking; while psychoanalysis itself dismisses efforts to be good as fruitless homage to a severe and unresponsive superego. Jones said of the conformity of Torontonians that 'one knew beforehand everyone’s opinion on every subject, so there was a complete absence of mental stimulation or exchange of thought.' 18

Jones's views on the sexual mores of North Americans matched the consensus amongst European psychoanalysts. For example, before Jung’s own distaste for the centrality of sex in psychoanalysis caused him to split from the Viennese analysts, the Swiss regularly cited the 'prudery' of Americans as an obstacle to psychoanalysis across the Atlantic. ${ }^{19}$ 'The so-called freedom of research in the land of the free,' Jung wrote to Freud in 1910, 'has indeed been well guarded - the very word "sexual" is taboo.' ${ }^{20}$ While Jones was in Toronto, Sándor Ferenczi wrote to him a sweeping assessment of North American sexuality, that might make us wince now, and not just for its old world condescension:

The cultural climate prevailing in the United States has the effect of 1) repressing heterosexuality (hence: admiration for women), 2) favouring (usually well-sublimated) homosexuality (sports, intimate friendships, politics, work 
teams.) To guard against the encroachment of homosexuality, women are then worshipped and admired in an even more exaggerated fashion. ${ }^{21}$

Perhaps Ferenczi hits on something in relation to the idealisations and sublimations of American public life, but there is also something here of the early analysts convincing themselves of their own courage in overcoming bourgeois prudishness about sex. Psychoanalysis ultimately took root the most successfully in America, but in this view it is a backward territory, steadfastly not wanting to know about the sexual factors that drive human action.

Freud was known to have quipped that America, was 'gigantic'.... 'a gigantic mistake'.22 This didn't mean that he took no interest in it, even if the psychological establishment in the United States was hostile to Freudian thought, for he was convinced that the future of psychoanalysis was in America. That is, for Freud, the future of European psychoanalysis lay in American financing. In 1909 he wrote to Ferenczi with admirable knowledge of Yankee slang that 'America should bring money, not cost money. By the way, we could soon be "up shit creek" the minute they come upon the sexual underpinnings of our psychology. ${ }^{23}$ Later, in the throes of austerity in Austria after WWI, Freud complained to Jones about the lack of American support for the psychoanalytic journals he had founded: 'What is the use of Americans,' he asked, 'if they bring no money?'24

As Jones’ Canadian acquaintances were keen to remind him, Canada is not the United States, and the two nations cannot be dissolved into each other, but Freud himself did not differentiate particularly between the two, and considered Jones' presence in Toronto simply part of psychoanalysis' inroads to 'America'. After the Clark lectures in 1909, the travelling party of Freud, Jung and Ferenczi made it as far as Niagara Falls, but when Jones invited Freud to Toronto, Freud took up James 
Jackson Putnam's invitation to his cabin in the Adirondacks instead. At Niagara, Jones recounts in his biography of Freud, 'They took a trip in the Maid of the Mists below the Falls and also set foot in Canada, to Freud's great pleasure. ${ }^{25}$ We know nothing more of what the father of psychoanalysis made of Canada and Canadians.

\section{Jones to Freud: development of an idea}

When Freud first proposes the narcissism of minor differences in his essay of 1917 on 'The Taboo of Virginity', he invokes the idea to explain hostility between the sexes rather than between nations or neighbouring communities:

it is precisely the minor differences in people who are otherwise alike that form the basis of feelings of strangeness and hostility (Fremdheit und Feindseligkeit) between them. It would be tempting to pursue this idea and to derive from this 'narcissism of minor differences’ (Narzißmus der kleinen Unterschiede) the hostility which in every human relation we see fighting successfully against feelings of fellowship and overpowering the commandment that all men should love each other. ${ }^{26}$

He picked up the idea again in 1921 in Group Psychology and the Analysis of the Ego. Now it is used to refer to differences between communities and nations, even if the exact term 'narcissism of minor differences' is not used:

Every time two families become connected by a marriage, each of them thinks itself superior to or of better birth than the other. Of two neighbouring towns each is the other's most jealous rival; every little canton looks down upon the others with contempt. Closely related races (Nächstverwandte Völkerstämme) keep one another at arm's length; the South German cannot endure the North German, the Englishman casts every kind of aspersion on the Scot; the Spaniard 
despises the Portuguese [....] In the undisguised antipathies and aversions (Abneigungen und Abstoßungen) which people feel towards strangers with whom they have to do (nahestehende Fremde) we may recognise the expression of self-love - of narcissism [....] We do not know why such sensitiveness should have been directed to just these details of differentiation (Einzelheiten der Differenzierung). ${ }^{27}$

Freud then revisited the idea in his final book, Moses and Monotheism (1939), but this time without mentioning narcissism. In the context of an exploration of the religious origins of the hatred of Jews, he notes 'Other grounds for hating the Jews':

They are not fundamentally different (grundverschieden), for they are not Asiatics of a foreign race, as their enemies maintain, but composed for the most part of remnants of the Mediterranean peoples and heirs of the Mediterranean civilization. But they are nonetheless different (sie sind doch anders), often in an indefinable way different (undefinierbarer Art anders), especially from the Nordic peoples, and the intolerance (Intoleranz) of groups is often, strangely enough, exhibited more strongly against small differences (kleine Unterschiede) than against fundamental ones (fundamentale Differenzen). ${ }^{28}$

In total there are four occurrences of the concept in Freud's writing, but only in two of these does Freud use the phrase that gained such currency subsequently. Even then, there are small differences: 'kleine Unterschiede’ in 1917 has by 1929 changed to ‘kleine Differenzen’, going by way of ‘Einzelheiten Differerenzierung’ in 1921. In 1939 Freud then reverts to 'Unterschiede’ for small differences, reserving 'Differenzen’ for the larger ones.

Ernest Jones’s letter on the Canadians precedes ‘The Taboo of Virginity’ by almost a decade, but is it the original source for the Freudian kleine Unterschiede? Or 
was he simply rendering in psychoanalytic terms a common observation about lessthan-loving neighbours? We know from Jones himself that Freud was not averse to exploiting narcissisms of minor difference. He reports that when they met in Salzburg, nine months before the letter from Toronto, Freud's 'first remark' was 'From the shape of your skull you can’t be an Englishman; you must be a Welshman.' Whether he divined this from my cranium, which I very much doubt, or from my name and perhaps facial expression, what struck me about the remark was that it was the only occasion I ever found anyone in Austria or Germany who knew of the existence of my native country. ${ }^{29}$

Freud in fact had this information in advance from Jung, who had met Jones in Amsterdam in 1907 and had noted then the Welshman's Celtic origins. ${ }^{30}$ If it matters who came first, then, we might say that Jones' letter on the Canadians was the continuation of a dialogue opened by Freud's flattery on their first meeting. What is clear is that Freud at no point credits Jones. His circuitous development of the concept might even lead us to suspect that he is covering any tracks that might lead back to his disciple. That is, Freud only arrives at the Jonesian formulation by way of detours, and when he completes the concept he has effectively reversed the perspective given by Jones on the Canadians. Or rather, the constituent elements are the same - hostility, narcissism, and minor differences - but Freud reconfigures their structural relations.

In the first iteration, the essay on the taboo of virginity, Freud makes no mention of nationality or ethnicity. Instead, he introduces the narcissism of minor differences through the relation between husband and wife in marriage. In other places Freud makes much of the psychical consequences of the difference between the sexes, but here suggests that the difference is only small, and for this reason is a 
potential source of hostility. The context is his attempt to account for 'the generalized dread of women' experienced by men in primitive, but also modern, cultures, and the taboos that arise around women as a result. ${ }^{31}$ When he then articulates the narcissism of minor differences, in the passage already cited, he credits the idea in the first instance to the English anthropologist Ernest Crawley, and his notion of a 'taboo of personal isolation'. In a notable choice of phrase, he claims that Crawley 'uses language which differs only slightly from (nur wenig von...unterscheiden) the current terminology of psychoanalysis' when he 'declares that...it is precisely the minor differences in people who are otherwise alike that form the basis of feelings of strangeness and hostility between them. ${ }^{32}$ There is thus a sort of rhetorical contagion at work: Freud is able to transmit the concept of minor differences between people thanks to a minor difference (nur wenig von...unterscheiden) between the disciplines of anthropology and psychoanalysis.

But one will look in vain in the source text that Freud refers to - The Mystic Rose: A Study in Primitive Marriage (1902) - to find the statement that Freud attributes to Crawley, in psychoanalytic or any other terms. What Crawley does provide is a model of tension and conflict between the two sides in marriage. According to Crawley, marriage ceremonies ritually acknowledge and dissolve this hostility:

marriage ceremonies have inherent in them, as binding the pair together, or neutralizing each other's dangerous influence, the intention and power to make their life harmonious and sympathetic ${ }^{33}$

In Jones's account of Canadians and Americans, this element of hostility is what is missing: the narcissistic Canadian is wounded by the mistake, but this is not because the American, in Jones's brief account, poses a threat. That Freud chooses to 
acknowledge the English anthropologist, who has not really spelt out the idea of minor differences in terms of narcissism, at the expense of the Welsh analyst who has, might be a symptomatic displacement, a displacement that also illustrates neatly an ethnic difference (between Welsh and English) considered small to all but the parties concerned.

In the second iteration of the concept, in Group Psychology, Freud introduces for the first time the question of national or ethnic identity already proposed by Jones. However, narcissism does not appear here until later in his argument and in a slightly different context, when he explains that 'antipathies and aversions which people feel towards strangers with whom they have to do' are an 'expression of self-love'. The phrase in English awkwardly translated as 'strangers with whom they have to do', is in German the much more economical 'nahestehende Fremde'. 'Nahestehende' can be translated simply as 'related', but it also contains as its root 'nahe', meaning 'near'. In other words, in this iteration, it is as much a question of the proximity of the stranger as it is his or her difference, minor or otherwise, that provokes narcissism. The thread linking this version with the first iteration is matrimony: Freud starts with families connected by marriage, moves to 'neighbouring towns', and finishes with 'closely related races'. The German phrase translated as ‘closely related races’ Nächstverwandte Völkerstämme - also implies in the first instance proximity or nearness, as do the 'neighbouring towns' (benachbarten Städten). We now also find a direct, if partial, trace of Jones: where the Welshman compares his insulted Canadian with rivalrous Spaniard and Portuguese, Dutch and Flemish, and Norwegian and Swede, Freud retains only the first pair, trading the others for the South German intolerant of his Northern cousin and the Englishman slandering a Scot. 
By the third iteration, in Civilization and its Discontents, Jones' disputatious Spaniard and Portuguese have become a regular feature. Freud also complicates the picture by adding an additional figure of aggression, but this time not as part of a pair: it is 'the Jewish people, scattered everywhere', who 'have rendered most useful services to the civilizations of the countries that have been their hosts.' Only now does Freud bring together the question of the narcissism of minor differences, and the question of proximity broached in Group Psychology. In Strachey’s translation we find: 'communities with adjoining territories, and related to each other in other ways as well'. In Freud's German, we have the same terms relating to proximity that he used in 1921: 'gerade benachbarte und einander auch sonst nahestehende Gemeinschaften'. It is, therefore, the situation of Jews in Europe that allows him to complete the idea, providing an example that combines proximity and (minor) difference. He goes on to drily observe that 'unfortunately all the massacres of the Jews in the Middle Ages did not suffice to make that period more peaceful and secure for their Christian fellows (christlichen Genossen)'. ${ }^{34}$ When he then returns to the idea in 1939 for its fourth iteration in Moses and Monotheism, the treatment of the Jews in Europe is again his example, although this time it is Nazism rather than narcissism that he invokes. The differences between peoples may remain small and ‘indefinable' (undefinierbarer Art anders), but in the fresh historical circumstances, Freud abandons the language of nearness. The Jews are not nahestehende, but instead an außenstehende Minderzahl, an 'extraneous minority’ in Strachey’s translation. A more politically loaded translation might be ‘alien within’; an anachronistically Lacanian one could even give us ‘extimacy’. (In his briefest of direct interventions on the subject, Lacan proposes idiosyncratically to translate the narcissism of minor 
differences as 'conformist terror', thereby calling attention to the coercive group identity secured through small differences.) ${ }^{35}$

\section{Freud's analysis of Jones}

Far-fetched as it might seem to seek in Jones' brief letter on the Canadians the basis of Freud's narcissism of minor differences, most of the elements of Freud's idea are already there, if not quite in the same order. We could go even further and say that Freud does not so much borrow from Jones, as provide an analysis of Jones’ letter through his modifications of it. What does Freud add to Jones then, and what does he change?

The most straightforward addition made by Freud to Jones is his introduction of hostility (Feindseligkeit) or aggression (Aggression) to the theory. In Jones, Canadians ‘are very insulted if called Americans', and Spanish and Portuguese are 'insulted at being confused with each other.' But there is no mention in Jones of hostility towards the American on the part of the Canadian, or towards the Portuguese on the part of the Spaniard. Narcissism, on the other hand, is strongly implied in the bruised vanity of the Canadian, who harbours an intense, if misplaced, sense of his own uniqueness. But this narcissism does not manifest itself in the presence of the American with whom the Canadian is easily confused, but instead to a third party, who is not directly concerned (that is, to Jones). In Freud, by contrast, the observing third party witnesses neighbours 'who are engaged in constant feuds and in ridiculing each other' ${ }^{36}$ In other words, their narcissism is not a concern with their image in the eyes of the third party, but instead a direct result of the encounter with the neighbour.

It is, however, not out of the question that Freud drew on Jones in this case, because hostility is already present in Jones’ analysis. This hostility is Jones' own for 
Canadians, whom he proceeds to insult in every possible way in the rest of the letter to Freud. The list is long: they are 'despicable', 'bourgeois', 'uncultured', 'rude', 'stupid’, ‘narrow and pious', 'naïve, childish', ‘sentimental’ and humourless. Although Jones does not exactly describe the hostility of the narcissism of minor differences in his judgment of Canadians, he manifests it himself in his vitriol towards 'colonials', a very large proportion of whom originate from the same islands as he does. It is as if Jones constructs the theory of the narcissism of minor differences, but fails to put it all together, keeping the elements separate and leaving it to Freud to condense them in a single structure. Freud therefore carries out a sort of dream analysis on Jones' letter, but in reverse. Where the condensations of the dream-work are usually undone in analysis so that component parts are revealed, here it is the condensed structure that is revealed from the component parts. This is in fact a method that Jones pioneered. He called the unconscious process 'decomposition' and added it to displacement and condensation as key techniques of the dream-work. ${ }^{37}$ Where the dream-work (or other unconscious mechanisms) decomposes dream thoughts into separate elements, and thereby disguises their relation to each other, the analysis recomposes, demonstrating the underlying whole.

The motive of the hostile attack on Canadians becomes apparent when the final piece of decomposition is undone. Jones' narcissism of minor differences separates him from his hosts in order to bring him closer to Freud and to a psychoanalytic community that values humour and culture as much as it disdains bourgeois morality, piety and sentiment. His contempt for Canadians' royalism and his ignorance of the King's birthday are equaled only by his devotion to the new monarch to whom the letter is addressed. Identification with a conventional ideal (Edward VII) is replaced by a new, more exclusive one (Freud). 
Freud therefore reworks Jones' hostility so that it is intrinsic, rather than extrinsic to narcissism. But if the origins of Jones' hostility to the Canadians are clearly contingent, this is not always the case in Freud's theory as it developed latterly. Just as Freud fails to settle on a single term to name his concept, so with hostility he prevaricates. Although Freud uses the same word - Feindseligkeit (hostility or animosity) - each time to describe the affective byproduct of the narcissism of minor differences, on each occasion after its first use in 'The Taboo of Virginity' he modifies it slightly. In Group Psychology, this hostility comes accompanied with 'antipathies and aversions' (Abneigungen und Abstoßungen); in Civilization and its Discontents, it is a manifestation of the Aggressiontriebe (aggressivity, or aggressive drive); and finally, in Moses and Monotheism it is part and parcel of the Intoleranz towards Jews. These slight differences are far from incidental, because each implies a different interpretation of the origins of hostility. If Feindseligkeit is the product of an innate tendency towards aggression, then Freud appears here to drift towards the primordialism that Brett St Louis warns against; whereas to speak of it as a form of intolerance introduces a social, ethical or political dimension to the narcissism of minor differences.

Separated by only nine years, Civilization and its Discontents and Moses and Monotheism each have their historically determining contingencies. In choosing the more emphatic ‘aggression’ in 1930, Freud pointedly writes against Wilhelm Reich and other politicised psychoanalysts who were attempting to merge psychoanalysis and Marxism. For these analysts, repression was the enemy of human potential, and ‘individual liberation from crippling neurosis’ could be combined with 'economic liberation from poverty.' 38 If Freud is unequivocal in his insistence that repression of a primary aggression is necessary to the security of civilization, it is at least partly 
because he wants to reject the opposing Reichian formula. ${ }^{39}$ Freud's flexibility in relation to these matters is evident in Moses and Monotheism, written in the shadow of state-sponsored anti-Semitism. In this new context Freud presents such hatreds not as inevitable, but as evolving and historical, even if the structures of that history are ancient, as the subtle change from 'aggression' to 'intolerance' indicates. It is also worth remarking that with the example of anti-Semitism given by Freud in both texts, the narcissism of minor differences is no longer reciprocal, as it is in the case of the Spaniard and the Portuguese, whose hostility, according to Freud, is mutual. On neither occasion when he invokes the concept in relation to the Jewish people does Freud make mention of their hostility in return.

With the example of anti-Semitism, Freud therefore introduces the possibility that the narcissism of minor differences might be experienced asymmetrically, with relative social or political power a determining factor. It is not a possibility that he entertains in relation to Englishman and Scot, nor does Jones take into account the balance of power between Canada and the United States in his analysis of Canadian narcissism. Jones does, however, propose an answer, if only humourously, to a question that is necessary and which threatens to throw the whole theory into doubt. That is, what exactly constitutes a minor difference? What allows us to distinguish between minor difference and major, and at what stage does one become the other? Is the point of the narcissism of minor differences that the minor difference is misconstrued as major? Or does the narcissism of minor differences construe difference where there is in fact none at all? In Freud, where the terminology shifts on each occasion, there is prevarication on this issue. In Jones, minor difference is calculated precisely at five per cent: the Canadian is nineteen parts American and one part 'colonial'. 
By rendering it in such absurd terms, Jones leads us to conclude that the difference is in fact insignificant and it is only narcissism that gives weight to the one part in twenty. The difference may be insignificant, but once we take into account asymmetrical power relations, as Freud does in his later iterations of the idea, it no longer matters whether the difference is real, but that it is taken to be so. As Karl Figlio notes in his account of the concept, 'the antipathy of the narcissism of minor differences does not arise as a consequence of difference, but in the creation of difference. ${ }^{40}$ He goes on to suggest that this engendering of difference is no less consequential for being hallucinatory:

The differences that spark violence are delusions, fostered by projection: that is implicit in the idea that the group is an ego ideal, whose demands are most immediately satisfied by violence against the non-ideal, demeaned, other. ${ }^{41}$ In this context it is worth remembering that in his major theoretical intervention on narcissism, Freud links self-love with the delusions of the paranoiac, whose libido is withdrawn from external objects. ${ }^{42}$ Narcissism may struggle to survive an encounter with difference, but the narcissist is in no position to evaluate the quality or magnitude of any difference from the other encountered. If Freud prevaricates on the difference between minor and major and offers no equivalent to Jones’ five per cent hypothesis, it is because the question is irresolvable.

\section{Porcupines}

The theory does not simply dissolve in the fluctuations of these differences that are always relative to the needs of narcissism, neither firmly minor nor major. This is because Freud adds one further element to what Jones so briefly sketched, tilting the emphasis of the theory from the question of difference to the pressures of proximity. 
On each occasion when Freud writes of the narcissism of minor differences, it is always in tandem with a closeness that provokes the phenomenon. Whether it is ‘Trennung’ (separation) and 'fernhalten’ (to keep away) in ‘The Taboo of Virginity’, or 'nahestehende’ (near-standing) in Group Psychology and Civilization and its Discontents, or außenstehende (outside-standing) in Moses and Monotheism, Freud's vocabulary always modulates the kleine Unterschiede with a language of distance and distancing. This spacing of minor differences indicates that it is not so much the other as the neighbour that is at stake in the theory.

Freud signals as much when he prefaces the discussion in Group Psychology with a reference to Schopenhauer's parable of the porcupines:

A company of porcupines crowded themselves very close together one cold winter's day so as to profit by one another's warmth and so save themselves from being frozen to death. But soon they felt one another's quills, which induced them to separate again. And now, when the need for warmth brought them nearer together again, the second evil arose once more. So that they were driven backwards and forwards from one trouble to the other, until they had discovered a mean distance at which they could most tolerably exist. ${ }^{43}$

The necessity for warmth and the discomfort of proximity therefore take priority over any moral or ethical law set up to govern social relations. Freud's suspicion of the injunction in Leviticus to 'love your neighbour as thyself', implied here, is spelt out in more detail in Civilization and its Discontents, where he observes that the injunction, obediently repeated in religious times, was no preventative to the regular slaughter of ones’ neighbours. It is openly against this Freudian grain that contemporary theorists Kenneth Reinhard and Eric Santner take up Freud with the aim of finding a way, however paradoxical, to love the neighbor in a Freudian way. This love is not for 
minor differences but rather for what Reinhard calls 'the kernel of jouissance that is both foreign, strange, and unrecognizable in the other and intimate to me' and for what Santner describes as 'that which is most objectlike, most thinglike about the other' ${ }^{44}$ In this way, the neighbour is neither reduced to a set of aggravating traits, nor a cosy friendly figure, but is acknowledged in his or her enigmatic core.

Santner and Reinhard have for a prickly travelling companion Slavoj Žižek, who reworks to other ends the parable of the porcupine in his own account of the neighbor. Asked to give his love to this figure, Žižek retorts 'No thanks!':

It is easy to love the idealized figure of a poor, helpless neighbour, the starving African or Indian, for example; in other words, it is easy to love one's neighbour as long as he stays far enough from us, as long as there is a proper distance separating us. The problem arises at the moment when he comes too near us, when we start to feel his suffocating proximity - at this moment when the neighbour exposes himself to us too much, love can suddenly turn into hatred. $^{45}$

In his various repetitions of the idea, Žižek nods to Freud, but his direct source is Lacan's Ethics of Psychoanalysis. In that seminar, Lacan says of Civilization and its Discontents that Freud 'talks of nothing but' the commandment to love one's neighbour: it 'is where he begins, where he remains throughout, and where he ends up'. ${ }^{46}$ The lesson there is not quite what Žižek makes it out to be, though, nor indeed what Reinhard and Santner claim in a more saintly key. Rather than the quills of our fellow porcupines making them unloveable if we get too close to them, love is precisely what allows us to get close, but avoid the encounter. As Kathleen O’Dwyer remarks in relation to Žižek, 'the avoidance of an encounter with the singular and concrete experience of the neighbour is propelled by an aversion to one's own 
vulnerability and lack, which might be mirrored in the other' ${ }^{47}$ It is an observation that brings us very close to the narcissism of minor differences after all.

Love's power to avoid the encounter is shared with the other two Lacanian 'passions', hatred and ignorance, which like love, are modes of misrecognition. Love, after all, Lacan repeats everywhere, always takes as its prototype and ideal narcissism. Love, then, is a means to keep the neighbor at the right distance, but self-love is also a means for the subject to avoid an encounter with itself. In Seminar 20: Encore, Lacan coins the term 'hainamoration' (hateloving) to capture the proximity of these two passions. ${ }^{48}$ And Julia Kristeva tells us that the ambivalent desire for and hatred of the 'Jew' (in Céline, but also more widely) is possible because he 'is under our skin, the very closest neighbor, the nearly same, the one we do not differentiate. ${ }^{49}$ What, one wonders, would Ernest Jones have encountered, what enigmatic core might he have found in those Canadians, reputedly so nice, so courteous, had he unburdened himself of his hatred-love for them? And would Freud, given the chance, have entered into as many contortions as Reinhard and Santner to accommodate the enigmatic neighbour, or would he have preferred Kierkegaard's view that the only neighbor one can truly love is a dead one ${ }^{50}$ It is reported that before his trip to America Freud said 'I am going to the USA to catch sight of a wild porcupine and to give some lectures' ${ }^{51}$ Perhaps he chose Putnam’s Adirondack cabin over Jones’ invitation to Toronto because he was more likely to encounter a porcupine in the Adirondacks. At the end of a long hike near the end of his visit, Freud finally came across a porcupine corpse.

For their advice on this article, I am grateful to Dani Caselli, Ken Hirschkop, Rob Lapsley, Nuria Triana-Toribio, and Ben Ware.

\footnotetext{
${ }^{1}$ The source is second-hand, from Jacques Lacan: 'Thus Freud's words to Jung - I have it from Jung's own mouth - when [...] they arrived in New York harbor and caught their glimpse of the famous statue illuminating the universe, “They don't realize we're bringing them the plague”, [...] attributed to him
} 
as confirmation of a hubris whose antiphrasis and gloom do not extinguish their troubled brightness.' Jacques Lacan, Écrits: A Selection, trans. Alan Sheridan (New York: Norton, 1977), p.116.

${ }^{2}$ Letter of December 10, 1908. The Complete Correspondence of Sigmund Freud and Ernest Jones 1908-1939, ed. R. Andrew Paskauskas (Harvard: Belknap Press, 1993), p.11.

${ }^{3}$ Sigmund Freud, Civilization, Society and Religion, Volume 12, Penguin Freud Library, ed. Albert Dickson, trans. James Strachey (London: Penguin, 1985), p.305.

${ }^{4}$ Michael Ignatieff, The Warrior's Honour: Ethnic War and the Modern Conscience (New York: Henry Holt, 1998), pp.48-71. See also Pål Kolstø. 'The “narcissism of minor differences” theory. Can it explain genocide and ethnic conflict?’ in Historia mot strömmen: Kultur och konflikt i det moderna Europa (Stockholm: Carlsson Bokforlag, 2007); and Kate E. Temoney 'The 1994 Rwandan Genocide: The Religion/Genocide Nexus, Sexual Violence, and the Future of Genocide Studies,' Genocide Studies and Prevention: An International Journal 10.3 (2016), pp.3-24 (pp.6-7).

${ }^{5}$ Pierre Bourdieu, Distinction: A Social Critique of the Judgment of Taste, trans. Richard Nice (London: Routledge, 1984), p.479. See also Anton Blok, 'The Narcissism of Minor Differences,' European Journal of Social Theory 1.1 (July 1998), pp.33-56 (p.38).

${ }^{6}$ Brett St Louis, 'The difference sameness makes: Racial recognition and the "narcissism of minor differences”’ Ethnicities 5.3 (2005), pp.343-64 (p.348).

${ }^{7}$ See Glen O. Gabbard, 'On Hate in Love Relationships: The Narcissism of Minor Differences

Revisited’ Psychoanalytic Quarterly LXII (1993), pp.229-38 (p.235).

${ }^{8}$ St Louis, 'The difference sameness makes', p.356.

${ }^{9}$ After meeting Jones, Freud wrote to Jung, May 3, 1908, 'Jones is undoubtedly a very interesting and worthy man, but he gives me a feeling of, I was almost going to say racial strangeness. He is a fanatic and does not eat enough [....] to his mind even I am a reactionary'. William McGuire, ed. The Freud/Jung Letters: The Correspondence between Sigmund Freud and C.G. Jung, trans, Ralph Manheim and R.F.C. Hull (London: Penguin, 1991), p.110.

${ }^{10}$ See, for example, Correspondence of Sigmund Freud and Ernest Jones, p.58.

${ }^{11}$ See Brenda Maddox, Freud's Wizard: The Enigma of Ernest Jones (London: John Murray, 2006), especially Chapter 6, 'Hamlet in Toronto'.

12 Maddox, Freud's Wizard, pp.80-1.

${ }^{13}$ Ernest Jones, Free Associations: Memories of a Psycho-Analyst (London: Hogarth Press, 1959), p.196.

${ }^{14}$ Jones, Free Associations, pp.193-4. The Montreal Opera Company was the 'most ambitious operatic enterprise ever undertaken in Canada', producing a touring programme between 1910 and 1913, coinciding almost exactly with Jones' time in Toronto. Helmut Kallmann, A History of Music in Canada 1534-1914 (Toronto: University of Toronto Press, 1960), p.207. See also Elaine Keillor, Music in Canada: Capturing Landscape and Diversity (Montreal and Kingston: McGill-Queen's University Press, 2006), p.387. In Toronto the company did not perform at Massey Hall, but at the Princess Theatre. See 'Montreal Opera Company', http://www.thecanadianencyclopedia.ca/en/article/montreal-opera-companycompagnie-dopera-demontreal-emc/. Consulted June 29, 2017.

${ }^{15}$ See 'Massey Hall', https://www.masseyhallandroythomsonhall.com/our-history/masseyhall/masseyhall-events/. Consulted June 24, 2017.

${ }^{16}$ Jones, Free Associations, pp. 195 \& 177.

17 T.G.Davies, Ernest Jones, 1879-1958 (Cardiff: University of Wales Press, 1979), pp.35-7.

18 Jones, Free Associations, pp. 196-7.

19 See Freud/Jung Letters, p.127.

${ }^{20}$ Freud/Jung Letters, p.186.

${ }^{21}$ Letter of 14 November, 1911. Sándor Ferenczi - Ernest Jones Letters 1911-1933, ed. Ferenc Eros, Judit Szekacs-Weisz, and Ken Robinson (London: Karnac, 2013), p.9. The letter from Jones to which Ferenczi is responding is lost.

${ }^{22}$ Cited by Jones, Free Associations, p.191.

${ }^{23}$ Letter of 10 January, 1909. The Correspondence of Sigmund Freud and Sándor Ferenczi, Volume 1, 1908-1914, ed. Eva Brabant, Ernst Falzeder, and Patrizia Giampieri-Deutsch, trans. Peter T. Hoffer (Cambridge, Mass: Belknap Press, 1993), p.33

${ }^{24}$ Letter of 25 September, 1924. Correspondence of Sigmund Freud and Ernest Jones, p.552. In 1914 Freud argued that 'the absence of any deep-rooted scientific tradition in America' meant there was less resistance to psychoanalysis there, and that 'precisely for this reason the ancient centres of culture, where the greatest resistance has been displayed, must be the scene of the decisive struggle over psychoanalysis.' Sigmund Freud, 'On the History of the Psychoanalytic Movement', in Historical and 
Expository Works on Psychoanalysis, trans. James Strachey (London: Penguin, 1986), pp.63-128 (p.90).

${ }^{25}$ Ernest Jones, Sigmund Freud: Life and Work, Volume Two: Years of Maturity, 1901-1919 (London: Hogarth Press, 1955), p.65

${ }^{26}$ Sigmund Freud, On Sexuality, Volume 7, Penguin Freud Library, ed. Angela Richards, trans. James Strachey (London: Penguin, 1977), p.272.

${ }^{27}$ Freud, Civilization, Society and Religion, pp.130-1.

${ }^{28}$ Sigmund Freud, The Origins of Religion, Volume 13, Penguin Freud Library, ed. Albert Dickson, trans. James Strachey (London: Penguin, 1985) p.335.

${ }^{29}$ Ernest Jones, 'The Early History of Psychoanalysis' Journal of Mental Science 100.418 (1954), pp.198-210 (p.202).

${ }^{30}$ Freud/Jung Letters, p.79.

${ }^{31}$ Freud, On Sexuality, p.271.

${ }^{32}$ Freud, On Sexuality, p.272.

${ }^{33}$ Ernest Crawley, The Mystic Rose: A Study of Primitive Marriage (London: Macmillan, 1902), p.350.

${ }^{34}$ Freud, Civilization, Society and Religion, p.305. The 'Genossen', Kenneth Reinhard tells us, 'is the one with whom we enjoy [...] the companion [....] the element of exteriority that has infiltrated the domestic space.’ Kenneth Reinhard, ‘Toward a Political Theology of the Neighbor’, in Slavoj Žižek, Eric L. Santner and Kenneth Reinhard, The Neighbor: Three Inquiries in Political Theology (Chicago: University of Chicago Press, 2005), pp.11-75 (pp.36-7).

${ }^{35}$ Jacques Lacan, Écrits, trans. Bruce Fink (New York and London: Norton, 2006), p.410. Lacan also invokes the concept to explain the practice of anonymous publication in his journal Scilicet, which experimented with the Bourbakist principle of unsigned articles (with the exception of his own pieces). In the introduction to the first issue of Scilicet Lacan explains that contributions were anonymous in order to overcome the 'narcissism of small differences'. Jacques Lacan, 'Introduction de Scilicet au titre de la revue de l'École freudienne de Paris,' Scilicet 1 (1968): 3-13. On how Nazi anti-Semitism 'formed the backdrop' of Moses and Monotheism, see Eric L. Santner, On the Psychotheology of Everyday Life: Reflections on Freud and Rosenzweig (Chicago: University of Chicago Press, 2001), pp.7-8.

${ }^{36}$ Freud, Civilization, Society and Religion, p.305

${ }^{37}$ See Ernest Jones, Hamlet and Oedipus (London: Victor Gollanz, 1949), p.131.

${ }^{38}$ James E. Goggin and Eileen Brockman Goggin, 'Politics, Ideology, and the Psychoanalytical Movement before, during and after the Third Reich,’ The Psychoanalytic Review 88.2 (2001), pp.15593 (p.157).

39 There is a detailed account of the relation between Civilization and its Discontents and Reichian analysis in Goggin and Goggin, 'Politics, Ideology', pp.157-65. See also Nick Totton, 'Conflict, competition and aggression,' in Nick Totton, (ed.) The Politics of Psychotherapy: New Perspectives (Maidenhead: Open University Press, 2006), pp.30-42 (pp.30-1).

${ }^{40}$ Karl Figlio, 'The dread of sameness: social hatred and Freud's "narcissism of minor differences.”' In Lene Auestad, (ed.) Psychoanalysis and Politics: Exclusion and the Politics of Representation (London: Karnac, 2012), pp.7-24 (p.8).

${ }^{41}$ Figlio, 'The dread of sameness', p.10.

42 Sigmund Freud ‘On Narcissism: An Introduction’ in Penguin Freud Library Volume 11, On

Metapsychology: The Theory of Psychoanalysis (London: Penguin, 1984), pp.68 \& 90. See also Janine Chasseguet-Smirgel, The ego ideal: a psychoanalytic essay on the malady of the ideal, trans. Paul Barrows (New York: Norton, 1985) pp.15-18 where Chasseguet-Smirgel relates narcissism to the denial of difference.

${ }^{43}$ Arthur Schopenhauer, Parerga and Paralipomena Volume II, Chapter XXXI, Section 396. Cited in Freud, Group Psychology, p.130. A fuller and more literal translation can be found in Schopenhauer, Parerga and Paralipomena: Short Philosophical Essays, trans. E.F.J. Payne (Oxford: Clarendon Press, 1974), pp.651-2.

${ }^{44}$ Reinhard, p.46; Eric L. Santner, 'Miracles Happen: Benjamin, Rosenzweig, Freud, and the Matter of the Neighbour' in Žižek, Santner and Reinhard, The Neighbor, pp.76-133, (p.125).

${ }^{45}$ Slavoj Žižek Enjoy Your Symptom!: Jacques Lacan in Hollywood and Out (London: Routledge, 2001), p.8. See also Slavoj Žižek, The Plague of Fantasies (London: Verso, 1997), pp.45-70 and The Parallax View (Cambridge, Mass.: MIT Press, 2006), pp.111-18. In the last text Žižek strays into a primordialism that goes well beyond anything found in Freud. Invoking 'the "neighbor" in its strict Freudo-Lacanian sense', he calls it 'the monstrous, impenetrable Thing that is the Nebenmensch, the Thing that hystericizes and provokes me’ (p.113). Like Freud in Civilization and its Discontents, Žižek 
has an opponent he seeks to discredit: for Reich, substitute Levinas, and we understand better the contingency of Žižek's extremist theory of the neighbour.

46 Jacques Lacan, The Ethics of Psychoanalysis 1959-1960: The Seminar of Jacques Lacan, ed. Jacques-Alain Miller, trans. Dennis Porter (London: Routledge, 1992), p.179. See also, pp.183-88.

${ }^{47}$ Kathleen O’Dwyer, ‘Žižek on Love’, Philosophy Now 77 (February/March 2010), pp.18-20 (p.18).

${ }^{48}$ Jacques Lacan, Encore: The Seminar of Jacques Lacan, Book XX, ed. Jacques-Alain Miller, trans. Bruce Fink (New York and London: WW. Norton, 1998), pp.90-98. As translator Fink points out, Lacan's neologism condenses the noun haine (hate) and the adjective énamoré (enamored).

${ }^{49}$ Julia Kristeva, Powers of Horror: An Essay on Abjection, trans. Leon S. Roudiez (New York: Columbia University Press), p.182.

${ }^{50}$ Søren Kierkegaard, Works of Love, trans. Howard Hong (New York: Harper, 1994), pp.74-5.

${ }^{51}$ George Prochnik, 'The Porcupine Illusion', Cabinet 26 (Summer 2007)

file://Users/ku/Desktop/CABINET\%20:\%20The\%20Porcupine\%20Illusion.webarchive Consulted July 3, 2017. 